\title{
CIRURGIA GERAL E O SISTEMA DE SAÚDE
}

\section{Alcino Lázaro da SiIva, TCBC-MG ${ }^{1}$}

O exercício da cirurgia no mundo contemporâneo pode ser dividido em operações gerais e especializadas. Quando se trata de hospitais universitários e grandes centros, apoiados em melhor sistema econômico, o geral se dilui quase completamente no especializado. A característica fundamental deste exercício operatório é o envolvimento de um ou mais especialistas para resolver um só problema. Quando, no entanto, caminhamos para os lados, que são os previdenciários, o exercício se inverte. Há na periferia dos grandes centros e no interior um volume de pacientes que não têm acesso fácil, ágil e eficiente às áreas gerais da assistência médica e, muito menos, e bem longe, dos especialistas.

Quem conhece o exercício clinicocirúrgico e o vive no quotidiano sabe que a solução dos problemas que os pacientes nos trazem é simples, dentro do prevalente e comum. Poder-se-ia dizer que, entre todas as atenções médicas, $70 \%$ a $80 \%$ são perfeitamente solucionadas nas sete áreas básicas da medicina: clínica médica, pediatria, cirurgia geral, ginecologia e obstetrícia e saúde mental, urgências, coroadas pela prevenção.

Se assim se coloca a medicina quotidiana, há que se hierarquizar o sistema. Como fazê-lo? Através de dois princípios.

No primeiro, a escola médica e o sistema de saúde têm que se dividir em duas partes distintas, que se seguem ou se complementam.

O que isto quer dizer? A escola, na primeira etapa, tem que formar o médico voltado para o prevalente e o comum, e o sistema de saúde tem que prestigiar as áreas básicas, criando trabalho mais fácil e mais ágil para os recém-formados. Na segunda etapa, a escola e o sistema têm que investir no especialista, prestigiando a residência (pós-graduação) e a reciclagem. A escola médica não termina na graduação. Seu maior compromisso é com esta. Não pode, no entanto, deixar de, junto ou no hospital universitário, assumir o controle didático e dar à residência e à especialização o conteúdo disciplinar do conhecimento. Não se pode conceber hospital universitário sem ação efetiva, contínua e esmerada da escola médica gerenciando os processos didáticos e disciplinares relativos à matéria que se estuda.

Nesse primeiro princípio fica fácil, pois, entender o papel didático da especialidade. O hospital universitário é uma empresa de prestação de serviço e antes de tudo um instrumento de ensino da faculdade para preparar o médico e o especialista. Este participará na graduação, fornecendo as bases e operações fundamentais de sua especialidade, que são os procedimentos limítrofes entre o geral e o especializado, perfeitamente desenvolvidos, com qualidade, por ambos. Na residência e no curso especializado ser-lhe-á, então, atribuída a responsabilidade de se aprofundar para qualificar um profissional que dê solução à propedêutica requintada e tecnológica e à demanda vertical do ato médico. O especialista, na graduação, deve participar como consultor e não como dirigente do processo didático, porque este tem que ser voltado para as áreas básicas, além, é obvio, da prevenção.

No segundo princípio, há que se prestigiar e remunerar muito bem o profissional que trabalha e desenvolve o sistema de atendimento básico. Isto aumentaria, certamente, o interesse e a formação de jovens. Uma parte somente dos médicos ficaria por mais tempo em formação, para tornar-se conhecedora mais profunda e mais vertical de uma área restrita ou especializada. Teríamos o maior contingente no ato médico comum, e o menor, no campo especializado ou vertical. As associações de classe cuidariam, com as escolas e os governantes, da atualização, reciclagem e estímulo da área básica, e as sociedades especializadas responsabilizar-se-iam pela reciclagem e defesa dos especialistas.

Sem querer ser simplista ou excessivamente racional a solução não depende tanto de dinheiro. Ao Ministério da Educação cabe um ato de coragem em reformular o ensino médico básico, adaptado a cada região do Brasil, sem fugir do objetivo de formar um homem que resolva bem o prevalente na assistência médica. Ao Ministério da Saúde, outro ato de coragem, enfrentando as opiniões contrárias ou interesses dirigidos, prestigiando o homem que atende as áreas médicas de que a população tanto carece. Em cima deste prestígio, remunerando-lhe bem para que haja dignidade profissional e humana e poder cobrar-lhe o aprimoramento contínuo e a manutenção da qualidade e eficiência.

A Cirurgia Geral (CG) imperou durante séculos como uma das áreas médicas de maior abrangência e capacidade para resolver problemas prevalentes e comuns. Com o desenvolvimento da tecnologia, o aumento do número de profissionais e o seu aperfeiçoamento dirigido aos setores específicos, a CG foi-se esvaziando. O esvaziamento tornou-se quase total na medida em que os centros maiores oferecem campo para aprimoramentos selecionados e os profissionais assim entenderam até para suas sobrevivências.

1. Professor Titular de Cirurgia do Aparelho Digestivo do Departamento de Cirurgia da Faculdade de Medicina da UFMG.

Rev. Col. Bras. Cir. 2002; 29(5):249-313-I 
Mas no torvelinho de pacientes com inúmeras doenças não existem especialistas suficientes nem na solução unilateral e, muito menos, na de equipe. Dentro da tecnologia de ponta consegue-se, a duras penas, absorver parte da demanda. No cotidiano, no comum e no prevalente, a cada dia, mais se avolumam as filas pela demanda aumentada ou represada.

Ninguém nega que há procedimentos nas especialidades que são divididos em avançados (tecnologia) e comuns (habilidade). Estes últimos, especialmente, saem de princípios e operações básicas ou fundamentais e estes, ninguém pode negar, saem da CG. Esta, como a palma da mão, sustenta os princípios e bases fundamentais e estes se distribuem pelas especialidades, enriquecidas pelos métodos e recursos tecnológicos requintados.

A CG, então, coloca-se na posição de mãe de todas as outras e pode exercitar-se, técnica e eticamente, nos casos comuns, prevalentes e limítrofes.

Se o sistema de saúde de um país quiser ter seu problema mais bem resolvido, mais ágil e menos oneroso tem que fazer cumprir e prestigiar determinados pontos vitais, a saber:

- incrementar as áreas básicas (v.g., CG)

- prestigiá-las

- remunerá-las dignamente, para não dizer melhor que para as especialidades

- reciclá-las periodicamente

- colocá-las no sistema em duas frentes: a do atendimento e a da seleção (triagem). Em CG, no atendimento, dependendo do hospital e da demanda, o cirurgião geral resolve de $70 \%$ a $80 \%$ dos casos. Na seleção ele é superior. Conhecendo os princípios e bases fundamentais, melhor orienta e melhor seleciona o paciente para o profissional especializado. Previne o perambular do paciente e evita gastos repetidos quando ele não é bem encaminhado. 